\title{
AS VÁRIAS FORMAS DE SER E ESTAR NAS RUAS: UMA ANÁLISE PSICANALÍTICA SOBRE PESSOAS EM SITUAÇÃO DE RUA
}

\section{THE VARIOUS WAYS OF BEING HOMELESS: A PSYCHOANALYTIC ANALYSIS OF HOMELESS PEOPLE}

Karin Priscila de Camargo ${ }^{1}$

Juliana Radaelli ${ }^{2}$

\section{RESUMO}

Esta pesquisa foi motivada pelo projeto Ciranda de Rua, o qual foi o resultado do estágio em psicologia comunitária, desenvolvido em Curitiba, Paraná, em 2015. Nesse projeto, constatouse serem recorrentes a discriminação e a violência da massa social contra as pessoas em situação de rua, sendo diversos os motivos que levavam as pessoas a esta situação. A partir dessas constatações, surgiu a hipótese de que a psicanálise possibilitaria compreender a forma como se estrutura e se mantém o laço social entre as pessoas em situação de rua, visto que a psicanálise se ocupa do singular do sujeito, e não do universal do fenômeno social. Para testar essa hipótese, foi realizada esta pesquisa com a participação de dez pessoas em situação de rua, frequentadores de uma ação assistencial realizada por uma associação filantrópica, diariamente. A pesquisa evidenciou as várias formas de ser e estar nas ruas, ao buscar identificar os laços construídos entre as pessoas em situação de rua, e entre elas e os trabalhadores da associação filantrópica. Foram realizadas visitas a campo para aplicar um questionário semiestruturado e coletar narrativas. Ao considerar a inconsistência do Outro, Lacan apontou para uma invenção do sujeito que lhe garantisse o laço com o outro. No caso das pessoas em situação de rua, concluiuse que o laço social se estruturava por um traço singular, sendo a rua o único elo em comum.

Palavras-chave: Pessoas em Situação de Rua. Laço Social. Sinthoma. Psicanálise.

\section{ABSTRACT}

This research was motivated by Ciranda de Rua, a project that resulted from an internship in community psychology, developed in Curitiba, Paraná, in 2015. In this project, it was found that the discrimination and violence of the social mass towards the homeless were recurrent and that several reasons led people to be homeless. From these findings, emerged the hypothesis that psychoanalysis would enable the understanding of how social bonds are structured 
and maintained among the homeless, since psychoanalysis takes care of the subject's individuality. To test this hypothesis, this research was conducted with the participation of ten homeless people, who attend, daily, a care action performed by a philanthropic association. The research evidenced the various ways of being in the streets, in seeking to identify the bonds built between the homeless, and between them and the workers of the philanthropic association. Field visits were carried out to apply a semi-structured questionnaire and collect narratives. In considering the inconsistency of the Other, Lacan pointed to an invention of the subject that guaranteed him the bond with others. In the case of homeless people, it was concluded that the social bond was structured by a singular trait, being the street the only link between them.

Keywords: Homeless. Social Bond. Sinthoma. Psychoanalysis.

\section{INTRODUÇÃO}

O fenômeno de ter pessoas em situação de rua existe desde a Grécia Antiga (Brasil, 2013). O que desperta a atenção é o crescente número de pessoas que vivem nas ruas, atualmente, em vários países, e as ações de exclusão e discriminação em relação a essas pessoas.

Este trabalho analisa as várias formas de ser e de estar nas ruas, tomando por base uma amostra de pessoas que viviam em situação de rua, em Curitiba, Paraná, em maio de 2019. Pelo viés da psicanálise, o trabalho aborda as formas de percepção adotadas pelas redes de sociabilidade, $\mathrm{e}$ as reações, muitas vezes, não inclusivas ou afetuosas em relação às pessoas em situação de rua. Estas reações resultam do processo de construção de identidade que se dá a partir do reconhecimento de semelhanças e diferenças. Em decorrência da noção de identidade coletiva, surge o fenômemo de oposição a outro grupo, como forma de afirmação da própria existência, assim a formação de identidade coletiva se constrói também no reconhecimento daquilo que a moralidade social de um grupo não se permite ser, à medida que considera as pessoas em situação de rua desviantes das normatizações estabelecidas (Ortega y Gasset, 2001).

As pessoas em situação de rua, geralmente, têm sua singularidade desconsiderada ao serem reconhecidas pelo que elas têm em comum: a estadia nas ruas. E não pelas suas singularidades. Este trabalho considera a rua como: a) um espaço onde pode se projetar o mais singular do sujeito, b) um espaço que rege as relações entre as pessoas em situação de rua e o "Outro" e, c) um espaço, que engloba a maneira como tais pessoas vivenciam o "laço social". Também desenvolve a entrada do sujeito na linguagem, a qual é fornecida pelo campo do Outro, e o efeito que essa entrada produz no sujeito à medida que ele constrói seu laço social:

O significante produzindo-se no campo do Outro faz surgir o sujeito de sua significação. Mas ele só funciona como significante reduzido o sujeito em instância a não ser mais do que um significante, petrificando-o pelo mesmo movimento com que o chama a funcionar, a falar como sujeito. (Lacan, 1964, p. 196). 
Conforme Veras (2009), inicialmente, Lacan problematizava o laço social a partir do Outro simbólico e, posteriormente, a partir do "gozo privado", termo que se refere a um prazer indizível e, impossível de ser expresso pelas palavras encontradas no campo do Outro. O laço social deixou, então, de ser visto como a possibilidade de comunicação garantida pelo Outro para ser apreendido como o modo pelo qual cada sujeito constrói saídas, a fim de encontrar uma articulação possível entre real, simbólico e imaginário. Articulação que torna capaz, a vida de um sujeito.

Aqui, as expressões "o mais singular do sujeito - sinthoma", "Outro", "laço social”, "Nome do Pai" e o "gozo" são entedidas como em Lacan $(1992,1998)$.

Para entender as várias formas de ser e de estar nas ruas, foram realizadas visitas a campo para entrevistar pessoas em situação de rua que aceitaram participar da pesquisa. Procurou-se averiguar os laços construídos entre elas e os trabalhadores de uma associação filantrópica, bem como as experiências positivas e negativas vivenciadas por elas, nessa associação. De forma complementar, foram ouvidos os trabalhadores dessa associação, a fim de identificar o laço deles com as pessoas em situação de rua.

\section{FUNDAMENTAÇÃO TEÓRICA}

\section{Sobre a População em Situação de Rua, no Brasil}

No Brasil, a presença de pessoas em situação de rua é um fenômeno histórico que acompanha o processo de urbanização e industrialização do país. É notável o aumento, ao longo dos anos, de pessoas que passam a encontrar na rua um lugar para a sobrevivência, de forma permanente ou temporária:

Percorrer distâncias, migrar, perambular, não possuir residência fixa é uma dinâmica social relatada desde a Grécia antiga. A denominação "situação de rua" só pôde advir após a sedentarização e construção de moradias familiares ou individuais da humanidade. Em épocas nômades tal concepção seria impossível (Brasil, 2013, p. 14).

Marc Augé (2012) apresenta o conceito de lugar, o qual contribui para a compreensão do conceito de rua. Para o autor, um lugar é uma invenção, descoberto por aqueles que o revendicam como seu, tendo três caracteristicas: identidade, relação e história. O lugar é um conceito que confere referência ao indivíduo, sendo delimitado por fronteiras simbólicas, etnias, regras e costumes. Em um lugar, podem coexistir elementos distintos e singulares, no entanto, esses elementos não impedem que as relações e a identidade sejam partilhadas e garantam sua ocupação. De acordo com Augé, ao existir um lugar consequentemente, existe um não lugar, e ambos, lugares e não lugares interpenetram-se.

O não lugar se refere aos espaços que não refereciam um indivíduo e, por essa razão permitem um anonimato. Os não lugares ao contraporem os lugares, são marcados por algo que escapa a opressão autoritária do Estado, dos costumes, das regras e das fronteiras. Nesse 
sentido, pode-se pensar a rua como um não lugar, como um espaço que confere ao sujeito certa liberdade. Pessoas se cruzam nas ruas, ruelas, trincheiras, avenidas e calçadas, mas ao final do dia voltam para o seu lugar, enquanto as pessoas em situação de rua, na rua permanecem. "É no anonimato do não lugar que se experimenta solitariamente a comunhão dos destinos humanos." Os imigrantes incomodam as pessoas instaladas porque, geralmente, demonstram a relatividade das certezas incritas no solo (Augé, 2012).

Uma das primeiras pessoas a viver nas ruas foi o filósofo Diógenes (323 a. C.), na Grécia Antiga. Ao ser expulso de sua cidade, Diógenes foi para Atenas onde conheceu seu mestre Antístenes. Seus únicos pertences eram um barril, onde vivia, uma lamparina, uma sacola e uma tigela, que simbolizavam autosuficiência e desapego em relação ao mundo. Diógenes fez da pobreza uma virtude e tinha como objetivo derrubar as instituições e os valores sociais. Ficou conhecido como o primeiro mendigo da história. Diógenes gerava desconforto na sociedade grega pela sua forma de existir perante à sociedade, e sua presença retratava o avesso àquela organização social. No entanto, fora admirado por Alexandre, o Grande, o qual ao se colocar em frente ao sol que aquecia Diógenes perguntou o que ele desejava, recebendo em resposta "não me tires o que não pode me dar" (Brasil, 2013).

A situação de rua é vista pela via do desconforto e da presença indesejada. Geralmente, a população em situação de rua é associada à violência e à incapacidade produtiva, fatores que lhes negam a inclusão na categoria de cidadãos de direitos, e fomentam atos de exclusão e de violência contra essa população. Como o ocorrido em Curitiba, em julho de 2018, em que duas pessoas em situação de rua foram encontradas mortas - um homem de 55 anos e uma mulher de 24 anos. De acordo com as informações de movimentos sociais, as mortes ocorreram em virtude de violência. Infelizmente, o caso não é isolado, tendo em vista que o Núcleo de Proteção aos Direitos da População em Situação de Rua do Ministério Público do Paraná realizou um levantamento e apontou que, entre 2016 e 2017, houve um total de 64 atendimentos a pessoas em situação de rua vítimas de violência (Wollmann, 2018; CRP-PR, 2018).

A população em situação de rua é representada por pessoas que habitam os não lugares, como os espaços públicos, os bancos, as praças, as marquises, os pontos de ônibus e as construções abandonadas. Essas pessoas carregam consigo seus pertences, papelão, colchões, cobertas, sacolas, além de uma aparência prejudicada pela exposição permanente à rua, pela falta de cuidados e, em alguns casos, pelo uso de drogas. Fatores que marcam um distanciamento com a sociedade, e fazem com que a massa social não os veja e, quando o faz, atravessa a rua, as estigmatiza com palavras hostis ou as considera um agente de violência urbana (Camargo et al., 2015; Wollmann, 2018).

A Pesquisa Nacional sobre População em Situação de Rua identificou 31.922 adultos em situação de rua, no Brasil. Essa pesquisa foi realizada em 2008, em 71 cidades brasileiras, sendo 23 capitais e 48 municípios com mais de 300 mil habitantes. Juntamente a outras pesquisas efetuadas em quatro capitais que não estavam contempladas na pesquisa anterior - São Paulo, Belo Horizonte, Brasília e Recife - totalizou-se 50 mil adultos em situação de rua, aproximadamente, nas capitais e em cidades com mais de 300 mil habitantes (BRASIL, 2009). 
De acordo com o Instituto de Pesquisas Econômicas Aplicadas (IPEA, 2016), o Brasil não contava com dados oficiais sobre a população em situação de rua, utilizando-se de dados disponibilizados por 1.924 municípios, via Censo do Sistema Único de Assistência Social. O Instituto estimou que existia 101.854 pessoas em situação de rua no Brasil, embora não informou estimativas precisas para cada município. Dessa forma, a atenção do Estado direcionada à população em situação de rua precisava acompanhar o mesmo crescimento.

Em relação ao gênero, a Pesquisa Nacional sobre População em Situação de Rua apontou que a população era predominantemente masculina (82\%) e mais da metade (53\%) tinha idade entre 25 e 44 anos. As principais razões para estarem vivendo nas ruas, indicadas na pesquisa, foram: problemas com álcool e outras drogas (35,5\%), desemprego $(29,8 \%)$ e desavenças com familiares $(29,1 \%)$. A pesquisa objetivou quantificar e caracterizar a população em situação de rua e, desde então, tem servido de referência para se compreender suas particularidades. (BRASIL, 2009)

Conceituar a expressão "população em situação de rua" é um exercício delicado, dada à pluralidade presente nas pessoas que compõem essa população, as diversas e distintas razões que as levam a fazer das ruas um espaço de sociabilidade e moradia, além da forma como o fazem. Definições que não abrangem essa pluralidade e não consideram a complexidade do tema, muitas vezes, se desdobram em insuficiências no processo de compreensão, além de contribuir para aumentar a estigmatização, os preconceitos e os atos de violência contra essa população (Camargo et al. 2015; Wollmann, 2018).

A definição para a expressão "população em situação de rua", utilizada pela Política Nacional para a População em Situação de Rua, foi instituída pelo decreto ${ }^{\circ} 7053$, de 23 de dezembro de 2009, e tem servido de base para as outras leis, a saber:

Grupo populacional heterogêneo que possui em comum a pobreza extrema, os vínculos familiares interrompidos ou fragilizados e a inexistência de moradia convencional regular, e que utiliza os logradouros públicos e as áreas degradadas como espaço de moradia e de sustento, de forma temporária ou permanente, bem como as unidades de acolhimento para pernoite temporário ou como moradia provisória (Brasil, 2009).

A partir dessa definição, as politicas setorias passaram a ser pensadas e reformuladas para incluir a população em situação de rua nos programas sociais. A política nacional para essa população tem como princípio o respeito, a dignidade, a equidade e a igualdade como condição para a garantia de direitos, retomando, assim a própria Constituição Federal promulgada em 1988, em especial, seus artigos 5ํ e 6oㅡ, os quais tratam inclusive do direito à moradia e à segurança. (WOLLMANN, 2018)

\section{A Psicanálise e o Avesso do Ideal}

O analista deve se situar no horizonte subjetivo de sua época (Lacan, 1992). Estar no horizonte subjetivo da época é estar em um lugar possível de olhar o passado e o futuro, 
para então compreender a inconsistência sobre os determinantes da cultura e, assim, adotar uma postura critíca em relação às crenças e aos valores estabelecidos e compartilhados pela sociedade. Segundo Crochik (2006) não existe sujeito sem cultura. Para o autor, o sujeito é produto da própria cultura e, se diferencia dela por sua singularidade. Porém, quando não consegue diferenciar-se da cultura, devido à grande identificação com ela, torna-se seu reprodutor, sem expressar críticas. Ao se tratar de uma cultura na qual predominam injustiças sociais, as criticas permitiriam modificar a cultura, tornando-a mais justa (Crochik, 2006).

No Brasil, impedimentos de acesso aos transportes coletivos, restrição para entrada em estabelecimentos comerciais, shoppings, bancos ou órgãos públicos, e restrições para atendimento na rede de saúde são as privações mais recorrentes, vivenciadas pela população em situação de rua, conforme apontado na Pesquisa Nacional sobre a População em Situação de Rua. Privações exercidas pela massa social que, ao estar regida pelos códigos sociais e culturais, delimita nos espaços públicos a segregação de todo sujeito que destoa da moralidade social estabelecida (Sasse \& Oliveira, 2019).

Na sociedade contemporânea, utilizar os espaços públicos como um local de moradia, certamente, não é sinônimo daquilo que poderíamos considerar desejável para um sujeito. A concepção, do que é moralmente aceito, é fomentada por crenças e valores culturais, tido como capaz de avaliar e evitar o risco que cada um corre de ser desviante ou de conviver com o desviante.

Geralmente, os discursos religiosos, juridícos e cientificos oferecem uma padronização acerca do humano, e tomam como desviante os comportamentos que não atendem a essa padronização. A exemplo do que ocorre nas sociedades que adotam o Manual de Diagnóstico e Estatístico de Transtorno Mental (DSM) como única referência científica para compreender a condição humana. O DSM abrange critérios diagnósticos que categorizam os transtornos mentais, na tentativa de enquadrar aquele sujeito que escapa a este modelo de compreensão sobre saúde mental e denuncia algo de estranho na sociedade; acrescentando-se a cada ano novas patologias mentais, resultando em um ideal sobre a normalidade humana, dificilmente alcançável, e menosprezando a subjetividade humana (Veras, 2009).

Segundo Veras (2009), a subjetividade humana não é considerada na avaliação quantitativa adotada pelo Manual de Diagnóstico e Estatístico de Transtornos Mental, uma vez que, apenas o que pode ser comparado ao outro é levado em conta. Dessa forma, é medido apenas o que é possível medir e na soma dos possíveis encontra-se certa concepção de normalidade, cientificamente possível. Ao que Lacan contrapôs-se, em entrevista ao Magazine Literáire sobre normalidade humana:

Quando eu escuto falar do homem da rua, [...] de fenômenos de massa e de coisas deste gênero, eu penso em todos os pacientes que eu vi passar sobre o divã, em quarenta anos de escuta. Nenhum deles, em qualquer medida, era semelhante ao outro, nenhum tinha as mesmas fobias, angústias, o mesmo modo de contar, o mesmo medo de não ser compreendido. O homem mediano, o que é isto? Eu, você, minha porteira, o presidente da República? (Lacan, 2004, apud Veras, 2009). 
A adoção de critérios diagnósticos e o consequente enquadramento do sujeito em categorias, produzem efeitos na saúde psíquica e na cultura. O território, considerado como o espaço que rege as trocas sociais, passa a ser ditado por um mestre que não leva em consideração as motivações subjetivas singulares a cada sujeito (Veras, 2009). Para ilustrar, tem-se a sociedade, supostamente voltada a promover o bem estar, e gerando um número cada vez maior de doenças mentais, pessoas estressadas, deprimidas e com fadiga crônica.

Nessa perspectiva, o perigo ocorre quando o discurso da ciência passa a agir de acordo com o "discurso do mestre", expressão proposta por Lacan (1992) como um dos quatro discursos que faz vínculo social, ao lado do "discurso do analista", do "discurso da histérica" e do "discurso universitário". Lacan representou cada um desses discursos por um algoritmo e em todos constam os mesmos símbolos: $\mathrm{S} 1=\mathrm{o}$ significante mestre; $\mathrm{S} 2=\mathrm{o}$ saber; $\$=\mathrm{o}$ sujeito; a = mais-de-gozar. $\mathrm{O}$ que muda entre os quatros discursos é a posição dos símbolos, e em cada posiçãoencontra-se uma designação específica. Segundo Veras (2009), na prática, o discurso do mestre encobre a divisão subjetiva do sujeito ao oferecer um significante mestre. Como efeito, a cultura, além de categorizar o estranho para manter a moralidade social, passa a segregar todo comportamento contrário às normas, sendo esse considerado desviante.

No final da década de 1920, o filósofo espanhol Ortega y Gasset alertava que o mundo tomado pela técnica forneceria as bases para a criação do homem mediano, o qual apresentaria um crescente horror ao desviante e à exceção. Para ele, a massa social era passiva e não apresentava desejos ou critérios próprios, características que negavam as duas principais condições da democracia: a autonomia intelectual e a participação em questões sociais. Segundo Ortega y Gasset, o homem da massa, geralmente era satisfeito, em perfeita harmonia com a homogeneidade e a indistinção social. Na maioria das vezes, demonstrava falta de projetos próprios, consumia e gozava das mesmas coisas que os outros, e tudo que escapava a essa normalidade era tido com desconfiança e comumente se transformava em alvo de segregação (Ortega y Gasset, 2001).

A segregação do estranho resulta do processo de contrução de identidade coletiva. É a partir do reconhecimento da diferença no desviante, o qual escapa as normatizações estabelecidas, que a massa constrói o ideal do eu, se recohecendo pelo que não deseja ser. $\mathrm{O}$ problema em questão é que aquele sujeito que não é como todo mundo, e não pensa como todo mundo corre o risco de ser eliminado (Ortega y Gasset, 2001).

Em contrapartida ao homem da massa, a psicanálise marca sua posição na recusa do homem normal ao atuar no sentido contrário às identificações estabelecidas com o outro. Segundo Veras (2009), a psicanálise age através do discurso do analista e opera através do "objeto a" que ao mesmo tempo é resto de gozo e causa de desejo. Dessa forma, a psicanálise evita que a subjetividade no campo humano seja tomada pela ciência em sua vontade de normatizar, quantificar e tratar a anormalidade.

De acordo com Veras, a psicanálise é por excelência a disciplina que pode se ocupar dos restos, justamente por não se ocupar do útil, do contábil ou do estatístico. Por não ter uma presença oficial dentro das instituições, lugar que implicaria uma cobrança de eficiência fundada na eliminação de qualquer resistência a um discurso institucional, a psicanálise 
possibilita o encontro com a singularidade do sujeito. Ela se dirige ao sujeito e procura resgatálo da condição de resto, condição que as pessoas em situação de rua, geralmente, são reduzidas pela sociedade, para questionar o sinthoma como um instrumento de conexão entre o gozo privado do sujeito e a linguagem pública do laço social.

\section{A Entrada na Linguagem e o Laço Social}

De acordo com Soler (2002), na psicanálise, trauma é algo que se impõe ao sujeito, ultrapassa-o, esmaga-o, colocando-o numa total falta de compreensão, diante de lembranças inesquecíveis e inassimiláveis. Lacan entendia como traumático o encontro com o Real, como aquele acontecimento que surpreende o sujeito, perfura, transborda sua capacidade psíquica de nomeação e, assim escapa a simbolização. O encontro do sujeito com as palavras vindas do campo do Outro imprimem uma marca na subjetividade, podendo resultar em ferida ou em marca determinante, inapagável. Em tal encontro, Lacan apontava um "efeito sujeito", pois entre todos os significantes ouvidos nas palavras do Outro, o sujeito escolhe aqueles que deseja reter. Nas relações interpessoais, o Outro com "o" maiúsculo, pode ser representado pelas figuras a quem o sujeito endereça uma demanda, os primeiros outros do bebê são a mãe, o pai, ou as pessoas que exercem essa função (Soler, 2002).

Independentemente do conteúdo das palavras encontradas no campo do Outro, a atribuição significante, a exemplo de “João é isto ou aquilo", se faz necessária para o advento do sujeito. Trata-se do nascimento simbólico e do fundamento do sujeito como ser. Tal atribuição reduz o sujeito a ser apenas um significante, reduzido ao que o Outro lhe significa ser. Não há outra saída para o sujeito, este fica condicionado a alcançar o que o Outro lhe atribui, pagando com o próprio ser (Soler, 2002).

A partir de Lacan, o inconsciente é um efeito de linguagem, não existe inconsciente possível para um ser que não seja constituído por ela. Mesmo antes de entrar na linguagem, o bebê é determinado através dela, no momento em que as figuras maternas e/ou paternas interpretam e satisfazem suas demandas iniciais. Dessa maneira, o bebê é capturado pelo campo do Outro, e fica submetido à lei da linguagem, a qual, enquanto articulação de significantes acopla os corpos, faz laço social, e torna-se um operador capaz de transformar o real (Soler, 2002).

Com a possibilidade de encontrar no campo do Outro, sentido ao desconhecido que habita o próprio corpo, o sujeito passa a fazer parte do laço social e a estar em movimento dialético com o Outro. No entanto, Lacan afirmou que o Outro é barrado e apontou para a impossibilidade de uma relação construída no modelo "problema solução" entre o sujeito e o Outro. Nem toda demanda encontra solução no campo do Outro, as respostas encontradas no Outro são insuficientes e há sempre restos que são excluídos de sentido, há um resquício daquilo que o sujeito em sua singularidade é incapaz de compartilhar com Outro. Resquicío que não se deixa capturar pela linguagem e escapa à simbolização, fazendo obstáculo ao laço social (Lacan, 1998; Veras, 2009). 
A partir disso, Lacan passou a questionar a organização das relações sociais e modificou a forma de pensar a inserção no social ao afirmar que o laço social não é puro efeito de discurso, pois inclui o corpo do sujeito e nele os efeitos impressos pela linguagem. Para Lacan, além das trocas intersubjetivas que ocorrem no laço social, o sujeito atrelado ao gozo incomunicavél do corpo é incapaz de responder aos ideais da socialização, pois sempre resta algo que escapa às tentativas de significação encontradas no campo do Outro (Veras, 2009). Esse fundo de incomunicabilidade condena o sujeito ao monólogo, ao um, e não ao dialógo com o Outro, por mais inserido que o sujeito esteja no laço social algo da sua satisfação permanece intraduzível pela linguagem, o que resulta na condição da própria existência. "Existir supõe a dor de ser lançado no mundo, supõe a linguagem que não dá conta de todos os juízos" (Ferrari, 2006).

Segundo Veras (2009), entre o Seminário 3, As psicoses e o Seminário 23, o Sinthoma é possível identificar um caminho traçado por Lacan que parte da garantia do Nome do Pai, tal como se apresenta no seminário 3, como ponto consistente do Outro e vai até o reconhecimento da inconsistência do Outro, o que altera profundamente a forma como o sujeito constrói uma resposta para a própria existência. Durante os vintes anos que separam esses seminários, o Nome do Pai pode se sustentar apenas se encontrar apoio no sinthoma. Ao não encontrar a garantia no Nome do Pai, que gozo e sentido são inseparáveis, o sujeito se força a uma invenção sobre os restos excluídos de sentido, chamados "objeto $a$ ". Lacan denominou essa invenção de sinthoma, expressão de sintoma que aponta para a singularidade do phatos irredutível à lógica coletiva na relação com o outro (Lacan, 1992).

Lacan postula o sinthoma como um elo que entrelaça os três registros real, simbólico e imaginário, e que “permite reparar a cadeia borromeana" (Lacan, 1975-1976, p. 90). Isso pode ser um ponto de ancoragem do sujeito, que pode encontrar o reconhecimento para o Outro, a partir de uma profissão, por exemplo. Bem como, ser morador de rua, andarilho, viajante, pode ser um título, um nome, uma articulação que confere ao sujeito uma referência para existir no mundo.

A partir das transformaçõesdo século XXI, como o declínio da esperança religiosa, o retraimento da família centrada na imagem paterna, Veras (2009) aponta para a precariedade do simbólico em relação ao real, o que fornece as bases para o sujeito conviver com a idéia de que o Outro não existe. Dessa forma, o sujeito passa a viver por própria conta e risco, desenvolvendo artificíos na tentativa de evitar a própria dissolução frente à inconsistência do Outro. Tal precariedade resulta na fragilização dos laços sociais tradicionais, no individualismo e na solidão crescente do sujeito. Enquanto o mundo caminha para se tornar uma grande comunidade globalizada, muitos sujeitos passam a se refugiar em uma posição individualista.

Como por exemplo, podemos citar a ascensão de comunidades sintomáticas onde as pessoas estão ligadas por um significante comum, como nos grupos de mútua ajuda anônimos: alcoólicos, narcóticos, bulímicos. Nessas condições sintomáticas, o gozo do sujeito é desalojado do campo do Outro, o que ocasiona a dissolução gradual do tecido social e faz 
surgir um número cada vez maior de sujeitos presos a um gozo solitário e conectados ao outro por um elo cada vez mais frágil. (Veras, 2009)

Diferente do proposto na década de 1920 por Freud, quando a teoria da identificação ocorria em torno da figura do líder, inspirada na própria imagem paterna, essa nova forma de identificação e associação de grupo não segue mais a identificação ao líder, ao Outro, uma vez que essa identificação acarreta em uma renúncia de gozo. Renúncia que está, a cada dia, mais distante dos pressupostos da contemporaneidade. Frente à inconsistência do Outro e à precariedade do simbólico, o sujeito passa a se organizar em torno de um modo de gozar em comum e não mais em torno da identificação da fígura parterna (Freud, 2011; Veras, 2009).

Enquanto a contemporaneidade é marcada por querer desembaraçar o sinthoma ao categorizar o sujeito em uma mesma patologia, patologizando e enquadrando sua forma de gozo, a psicanálise afirma que a solução clínica passa pela formalização de um sinthoma. Não se trata de eliminar a solução sintomática do sujeito, mas de encontrar um esforço do sujeito para isolá-lo como criação. Dessa forma, o sinthoma não deve ser tomado como algo a ser decifrado pela linguagem, mas como uma criação do sujeito, que não se alimenta no deciframento pela linguagem e no gozo de sentido encontrado no campo do Outro. Ao considerar a singularidade do sujeito, sua forma de gozo e sua solução sintomática percebe-se que cada um encontra uma saída singular que lhe garante o laço com o Outro. Em algumas situações, a forma de gozo encontrada pelo sujeito, entra em oposição à moral vigente para um determinado grupo (Veras, 2009).

\section{METODOLOGIA}

Este trabalho foi realizado a partir de pesquisa de campo, levantamento estatistíco, pesquisa exploratória e bibliográfica.

A pesquisa de campo ocorreu na associação filantrópica Acolhida Franciscana Bom Jesus dos Perdões, localizada na rua 24 de Maio, 135, Centro, Curitiba, Paraná, em maio de 2019, e foi composta por quatro encontros, com duração de duas horas cada, descritos a seguir.

10 encontro: O objetivo foi escutar as assistentes sociais e observar a prática de trabalho, na associação. As assistentes sociais atuam todos os dias com as pessoas em situação de rua. Durante o encontro, elas apontaram as angústias, os desafios e os ganhos obtidos com o trabalho na associação. Ainda, foi possível conhecer dois voluntários que auxiliavam as assistentes sociais, os quais, no passado, participavam do chá oferecido pela associação na condição de pessoa em situação de rua.

2o encontro: O objetivo foi acompanhar o preparo e a distribuição do chá, por um grupo de voluntários da associação composto, em sua grande maioria, por mulheres entre 70 e 80 anos atuantes da Igreja católica Bom Jesus dos Perdões, bem como a interação entre os voluntários e a população em situação de rua. 
3o e 4ำ encontros: $\mathrm{O}$ objetivo dos dois últimos encontros foi aplicar os questionários, enquanto as pessoas aguardavam na fila para o início do chá e, posteriormente, dentro da associação, onde o chá é servido. Ainda, observar a interação entre as pessoas em situação de rua e entre elas e os trabalhadores da associação.

No levantamento estatistíco, a amostra foi de conveniência, composta por dez pessoas em situação de rua que aceitaram responder um questionário semi-estruturado, elaborado para identificar como as pessoas em situação de rua estruturam o laço social. Além disso, foi feita uma pesquisa exploratória a partir de narrativas coletadas e situações observadas, não previstas no questionário citado que, posteriormente consistiram em um diário de campo.

A pesquisa bibliográfica foi realizada através do viés psicanálitico e abordou os conceitos de "sinthoma", "Outro", "laço social”, "Nome do pai" e "gozo privado", postulados por Lacan.

\section{RESULTADOS}

\section{Local da Pesquisa de Campo}

A pesquisa de campo foi realizada na associação filantrópica Acolhida Franciscana Bom Jesus dos Perdões. Conforme entrevista com as assistentes sociais, realizada in loco, em 19/03/19, a associação oferece um chá da tarde para pessoas em situação de rua, de segunda à sexta-feira das $14 \mathrm{~h} 30$ às 15h30, atendendo em média 150 pessoas ao dia. Além do chá, a Acolhida Franciscana realiza atendimento assistencial às pessoas em situação de rua, com doação de roupas, distribuição de kit higiene, elaboração de currículos, assessoramento jurídico, encaminhamentos para os centros de atenção psicossocial, para vagas de emprego e para reemissão de documentos. O assessoramento juridíco é realizado por um voluntário da área de direito, através do programa Justiça Restaurativa, e trata de questões jurídicas referentes à pensão, divórcio e união estável. Esses atendimentos ocorrem de forma individual, de segunda a quinta-feira, das $13 \mathrm{~h}$ às $17 \mathrm{~h}$.

Hoje, a associação conta com um quadro de cinco funcionários contratados, composto por coordenadora, assistente social e três estagiários de serviço social, além de 65 voluntários regulares. O voluntariado é formado, em sua grande maioria, por mulheres entre 60 e 80 anos atuantes da Igreja católica Paroquia Bom Jesus dos Perdões, instituição mantenedora da Acolhida Franciscana.

\section{Dados do Levantamento Estatístico}

Os dados quantitativos obtidos com a aplicação do questionário semiestruturado, junto às pessoas em situação de rua, estão apresentados por meio dos gráficos 1, 2 e 3,adiante.

Pelo Gráfico 1, constata-se que as pessoas em situação de rua entrevistadas declararamse do sexo masculino, predominantemente. 


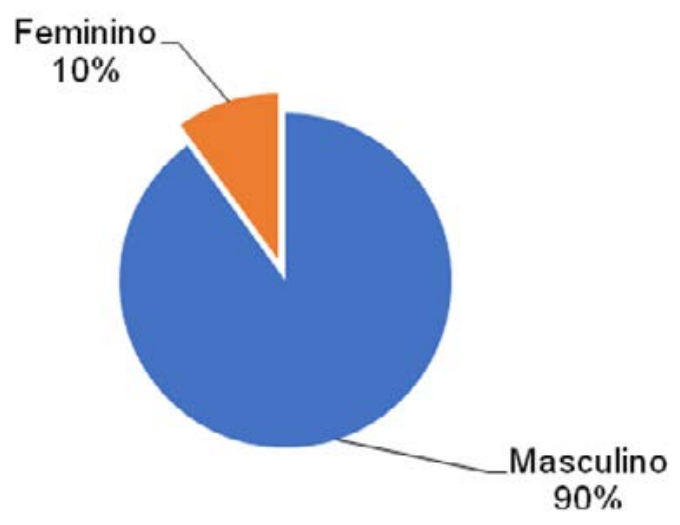

Gráfico 1. Pessoas em situação de rua que participaram da pesquisa "As várias formas de ser e estar nas ruas", segundo o sexo - Curitiba - Maio/2019.

Nota. Os percentuais foram calculados sobre um total de 10 pessoas entrevistadas.

Pelo Gráfico 2, em relação à idade, $40 \%$ dos entrevistados afirmaram estar entre 20 e 30 anos; $30 \%$ afirmou estar entre 30 e 40 anos, $10 \%$ afirmou estar entre 40 e 50 anos e $20 \%$ declarou ter 60 anos ou mais. Sobre o tempo em que os entrevistados estão em situação de rua, conforme o Gráfico 2, 10\% deles declararam viver nessa situação há 72 meses, 10\% há 60 meses, $20 \%$ entre 20 e 30 meses, $10 \%$ entre 10 e 20 meses e $50 \%$ há menos de seis meses, sendo que, dentre os últimos, dois entrevistados pagam um quarto de pensão, atualmente.

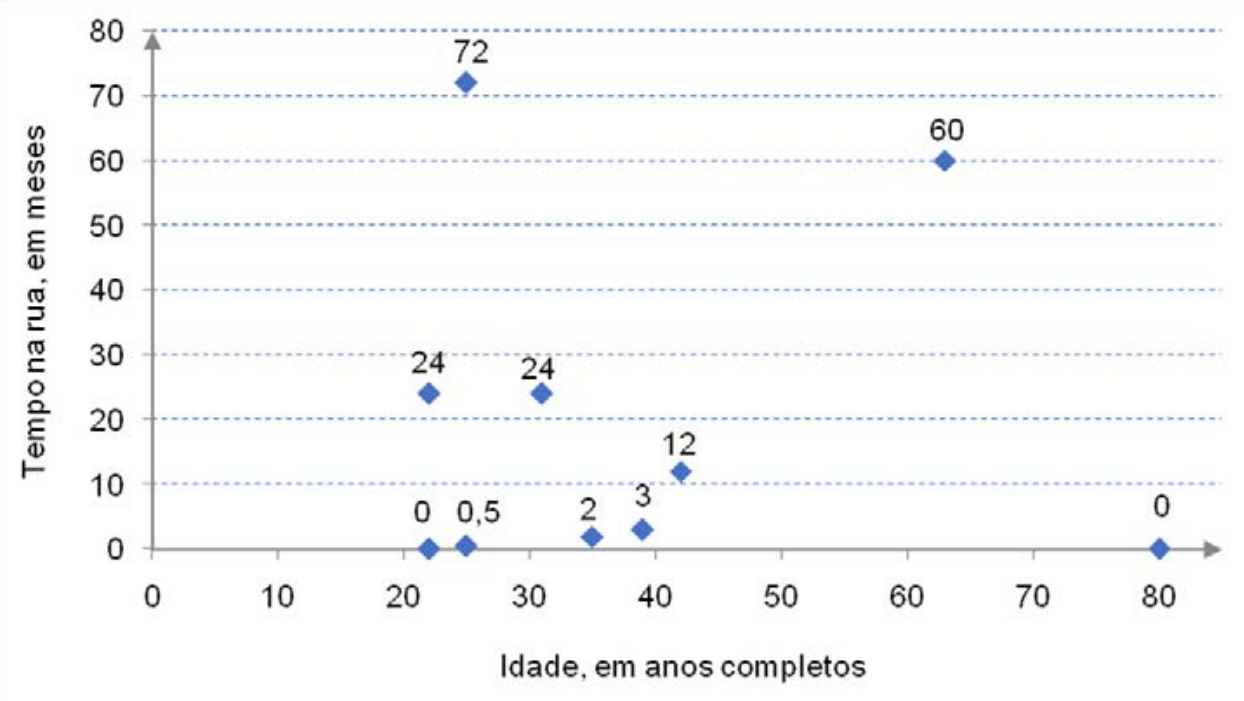

Gráfico 2. Pessoas em situação de rua que participaram da pesquisa "As várias formas de ser e estar nas ruas", segundo a idade, em anos completos, e o tempo na rua, em meses - Curitiba - Maio/2019.

Nota. Os percentuais foram calculados sobre um total de 10 pessoas entrevistadas. 
Dentre os entrevistados, o frequentador mais antigo da associação para tomar o chá declarou frequentar o chá há 48 meses, o que corresponde a 10\% dos entrevistados. Outros dois entrevistados declararam frequentar o chá há 24 meses (20\%). Os demais entrevistados declararam frequentar o chá há 18 meses (20\%), 12 meses (10\%), 6 meses (10\%), 2 meses (10\%) e 2 dias (20\%). Ver o Gráfico 3, abaixo. Ainda, pelo Gráfico 3, constata-se que os entrevistados que frequentam o chá 12 meses ou mais o fazem de quatro a cinco vezes por semana.

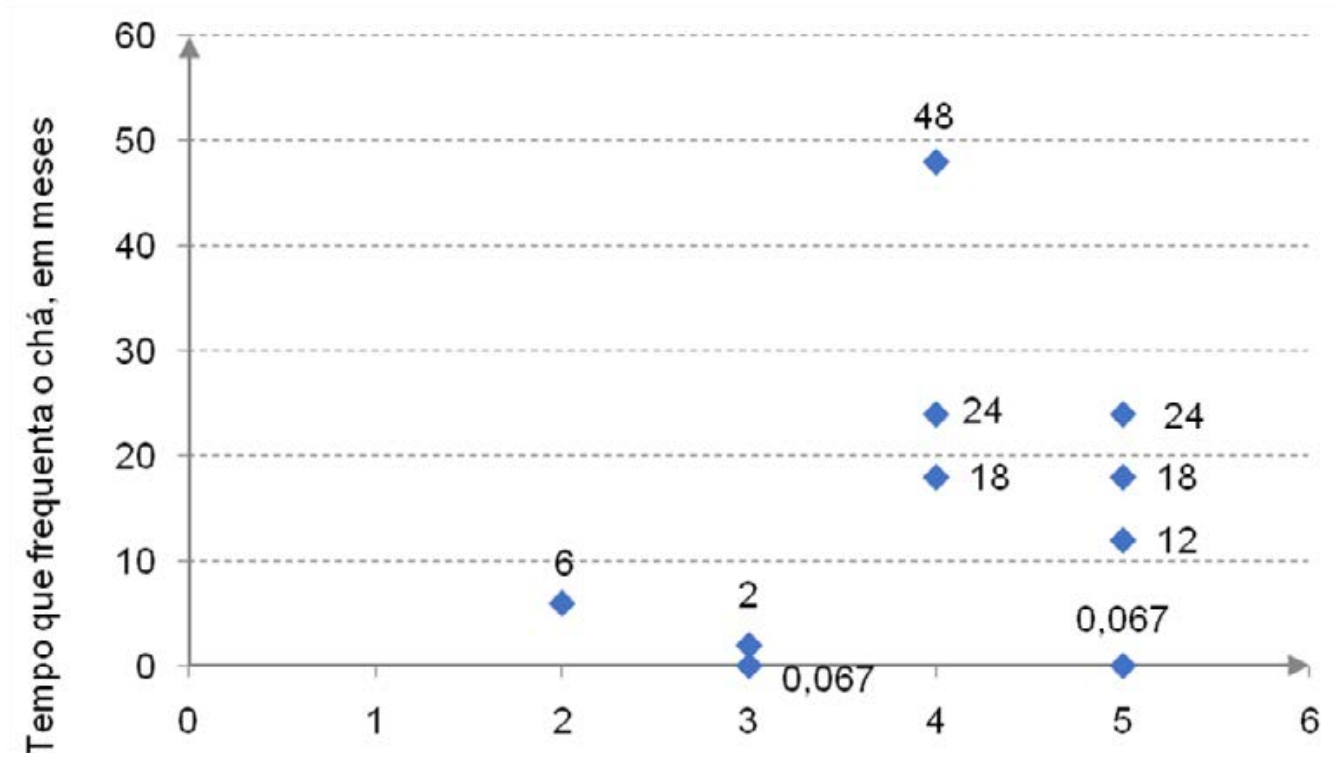

Gráfico 3. Pessoas em situação de rua que participaram da pesquisa "As várias formas de ser e estar nas ruas", segundo a frequência semanal ao chá e o tempo que utiliza a associação para tomar o chá - Curitiba - Maio/2019

Nota. A associação é a Acolhida Franciscana Bom Jesus dos Perdões.

Em relação à naturalidade, $70 \%$ das pessoas entrevistadas são naturais de cidades do Paraná. Dentre essas, três pessoas são naturais de Curitiba e quatro de outras cidades. Do total de entrevistados, $20 \%$ são naturais de outros estados do Brasil e 10\% de outro país. Todos os entrevistados declararam já ter exercido alguma profissão. Quanto à existência de vínculo familiar, $80 \%$ dos entrevistados afirmaram manter vínculo com algum familiar, enquanto $20 \%$ não. As motivações apontadas para estarem vivendo em situação de rua foram o desemprego (20\%); gostar de Curitiba (10\%); morte de ente querido (10\%); busca de novas oportunidades (10\%); falência do negócio (10\%) e dependência química (20\%). Os resultados estão apresentados no Quadro 1, abaixo. 
Quadro 1

Pessoas em situação de rua que participaram da pesquisa "As várias formas de ser e estar nas ruas", segundo a naturalidade, a profissão, o número de filhos, a existência de relação com familiares e os motivos para viverem/estarem em situação de rua - Curitiba - Maio/2019

\begin{tabular}{|c|l|l|r|l|l|}
\hline № & Naturalidade & \multicolumn{1}{|c|}{ Profissão } & Filhos & $\begin{array}{l}\text { Relação com } \\
\text { Familiares }\end{array}$ & Motivos de viver na rua \\
\hline 1 & Castro PR & Vendedor (a) & 0 & Sim & Desemprego \\
\hline 2 & Curitiba PR & Chapeiro & 1 & Sim & - \\
\hline 3 & Paranaguá PR & $\begin{array}{l}\text { Auxiliar de padeiro/ } \\
\text { funilaria }\end{array}$ & 4 & Sim & $\begin{array}{l}\text { Dependência química, mas } \\
\text { hoje sem uso. }\end{array}$ \\
\hline 4 & Curitiba PR & $\begin{array}{l}\text { Garçom; caixa; } \\
\text { atendente de } \\
\text { telemarketing }\end{array}$ & 0 & Sim & Falência do negócio \\
\hline 5 & Pitanga PR & $\begin{array}{l}\text { Trabalho com } \\
\text { construção civil }\end{array}$ & 3 & Sim & $\begin{array}{l}\text { Gostar da cidade + falta de } \\
\text { dinheiro }\end{array}$ \\
\hline 6 & Colombia & Artesão & 0 & Não & $\begin{array}{l}\text { Desemprego + busca de } \\
\text { novas oportunidades }\end{array}$ \\
\hline 7 & Junqueira AL & $\begin{array}{l}\text { Armador de } \\
\text { ferragem }\end{array}$ & 3 & Sim & Desemprego \\
\hline 8 & Curitiba PR & Eletricista & 1 & Sim & Dependência química \\
\hline 9 & Santana - BA & Pintor & 2 & Não & Falecimento da esposa \\
\hline 10 & $\begin{array}{l}\text { Santo Antônio } \\
\text { da Platina PR }\end{array}$ & Sapateiro & 1 & Sim & - \\
\hline
\end{tabular}

\section{DISCUSSÃO DOS RESULTADOS}

\section{Histórias que se Encontram nas Ruas}

Uma das questões que norteou esta pesquisa foi por que você está na rua? A partir desse questionamento, foram encontradas algumas respostas marcadas por questões subjetivas, as quais estão transcritas a seguir:

"Iniciei um negócio de venda de bebidas com um amigo; ele tinha problemas com álcool e acabou consumindo todo nosso estoque. Fiquei sem dinheiro. Pesou a idéia de ser mais uma boca para meu pai sustentar. Prefiro tentar me virar sozinho e não incomodar a família. Falo toda semana com a minha mãe. Comecei a cantar e tocar nos ônibus, além de vender balas no sinal; assim vou me virando" (N. 25 anos, em situação de rua há duas semanas).

"Minha esposa faleceu há dez anos e, desde então, estou nas ruas. Tenho três filhos, mas não os vejo faz alguns anos"(R. 63 anos, em situação de rua há cinco anos). 
"Fui demitido e vim pra Curitiba buscar melhores oportunidades. Meu dinheiro acabou e me apaixonei pela cidade. Não consegui outros trabalhos e acabei ficando, eu adoro aqui" (A. 31 anos, em situação de rua há dois anos). Neste relato, percebe-se que a rua é tomada como um lugar para esse sujeito. Pelo tempo em situação de rua, mostra que nela a vida é possível.

"Eu não estava muito a fim de nada, não queria fazer nada (...) trabalhar, estudar, nada. Fiquei um ano e meio nessa situação daí eu mudei, agora trabalho de chapeiro, mudei minha convivência com as pessoas, a forma de tratar elas"(A., 22 anos saiu das ruas há um ano).

"Estou desempregada há dois anos, as contas foram chegando e vim para as ruas. Minha mãe me abandonou quando nasci e meu pai morreu há dezenove anos" (AC. 22 anos, em situação de rua há um ano e meio). O Abandono marca uma motivação subjetiva para a vivência na rua.

"Eu trabalhava no quartel, mas acabei me envolvendo com as drogas. $\mathbf{O}$ vicío acabou comigo, fui expulso do exército e fui pras ruas. Hoje me recuperei e há dois anos não uso mais. Estou procurando emprego, mas está difícil com nosso cenário político" (A. 25 anos, em situação de rua há seis anos).

A Pesquisa Nacional sobre População em Situação de Rua (PNPSR) apontou os problemas com álcool e outras drogas como a razão mais indicada para estar em situação de rua, seguida do desemprego e das desavenças familiares (Brasil, 2009). Geralmente, apenas o abuso de drogas é atrelado à condição de estar na rua, no entanto, percebe-se nas narrativas que as motivações que levam as pessoas a essa situação, são singulares, assim como, as outras razões apontadas na PNPSR. Nesse relato, o abuso das drogas evidencia as rupturas de laços que sucederam a ida do sujeito para as ruas. Para cada caso de uso ou abuso de drogas existem particularidades, nem todo caso configura dependência e pode ser chamado de toxicômania. O fenômeno da toxicômania tenta anular o Outro, por mais que exista no uso da droga uma tentativa de comunicar algo ao Outro seja, um pedido de amor, um chamado de atenção ou de qualquer outra situação, essa tentativa fracassa. Isso ocorre, porque o encontro com a droga produz uma marca de prazer no corpo do sujeito, o qual passa a repetir essa experiência na busca do prazer perdido do primeiro encontro com a droga, a cada novo encontro. Assim, a droga não é causa de desejo, ela é um objeto de gozo, um objeto da mais imperiosa demanda que anula o Outro, desta maneira, a droga é compreendida como objeto de acesso a um gozo que não passa pelo campo do Outro (Nogueira Filho, 2001).

Nenhum dos entrevistados respondeu a entrevista da mesma maneira, em concordância com a concepção de normalidade de Lacan, a qual contraria a possibilidade de uma padronização acerca da subjetividade humana. A forma como contaram suas histórias, como pontuaram as motivações por hoje estarem, ou não, em situação de rua, e o aceite em participar da pesquisa denúncia a singularidade de cada um. Mostraram-se curiosos, desconfiados, falantes, receptivos e carentes. Outros aceitaram participar da pesquisa a partir do incentivo do colega, com isso, sentindo-se mais seguros e confiantes.

Esses sujeitos carregam consigo histórias e mazelas, o que, em alguns casos, torna a bagagem pesada, mesmo que andem com poucos ou nenhum pertence. Anteriormente a situação de rua, os entrevistados estabeleceram relações com o Outro e vivenciaram rupturas 
nessas relações. Hoje, esses sujeitos encontram-se ligados por um elemento em comum, a rua. Como visto em Lacan (1975-1976), o sinthoma é uma invenção do sujeito, capaz de entrelaçar os três registros: real, simbólico e imaginário. Para esses sujeitos, a rua pode ser um ponto de ancoragem e uma articulação possível, que os confere certa referência para existir no mundo e fazer laço social.

\section{A Rua e suas Saídas}

Cada um dos entrevistados relatou uma vivência singular que marca sua experiência na rua, seja pelo uso dela como local de morada temporária ou permanente, ou ainda, pelo que encontram ao estarem nessa situação, como os serviços disponibilizados pelas ações assistenciais, oferecidas por instituições religiosas ou por associações filantrópicas, ou como os serviços da rede desenvolvida e disponibilizada pela Fundação de Ação Social, mantida pela Prefeitura de Curitiba, como nas narrativas transcritas a seguir:

"Na rua, você encontra muitas possibilidades. Eu cuido dos carros, vendo balas no sinal e assim vou me virando".

"Sei onde eu consigo café, almoço, lavar as roupas (...) assim vou vivendo".

"Conheci uns amigos na rua e agora cantamos juntos nos ônibus".

"Não sei roubar, não sei pedir. O que eu posso fazer? Graças a Deus eu tenho aqui (...) me ajudam muito".

"Curitiba trata bem o morador de rua, em outras cidades o pessoal não gosta."

Como visto em Veras (2009), o laço social não é puro efeito de discurso, ao incluir o corpo e com ele um gozo privado que não encontra sentido no campo Outro. Comumente, a forma de gozo encontrada pelos entrevistados entra em oposição a outros grupos sociais, os quais são regidos por princípios considerados moralmente aceitos. Isso pode resultar em experiências discriminatórias e de segregação sobre as pessoas em situação de rua. Para ilustrar, tem-se a dificuldade de um dos entrevistados em conseguir trabalho ao informar o endereço do albergue:

"Eu trabalho na construção civil, vim de São Paulo para cá, desde que cheguei tô na rua, hoje, faz noventa dias. Não consegui trabalho; quando digo o endereço do albergue ninguém contrata" (M. 39 anos, em situação de rua há três meses).

\section{A Pessoa em Situação de Rua}

Um dos entrevistados não se identificou como pessoa em situação de rua. Anteriormente à rua, os entrevistados carregam consigo os significantes que os acompanham nessa trajetória. No entanto, ligam-se uns aos outros pela condição sintomática de estarem na rua. Como pode ser visto na narrativa transcrita a seguir:

"Eu não sou uma pessoa em situação de rua, durmo no albergue".

A partir da identificação com o termo pessoa em situação de rua, as pessoas passam a se agrupar em torno do significante rua. Existem iniciativas e movimentos organizados 
por pessoas em situação de rua, para a reivindicação de direitos e para busca de maior visibilidade sobre a violência que enfrentam ao estarem nessa condição. Um dos maiores movimentos de pessoas em situação de rua é o Movimento Nacional da População de Rua (MNPR), criado em 2005 para enfrentar os riscos na rua, lutar contra o preconceito, a discriminação e, as violações dos direitos humanos. Em 2008, um representante do MNPR entrou para o Conselho Nacional de Assistência Social, sendo o primeiro representante de movimento popular eleito. (MNPR, 2010)

\section{Os Laços Dentro da Associação}

Verificou-se que os entrevistados passam a existir dentro da associação à medida que são reconhecidas pelos trabalhadores que os acolhem. Consequentemente, foi possível identificar a existência do laço social entre essas pessoas em situação de rua e, as assistentes sociais, $o$ Frei e uma das voluntárias que, frequentemente surgiram nas narrativas dos entrevistados:

"Eu to sentindo falta do Frei, acho que ele está viajando".

"Aquela assistente (...) ela sempre me ajuda".

"Das voluntárias tem a vó, ela sempre cuida da gente. Na quarta e na sexta-feira ela está aqui”.

O Frei, a vó e a assistente social estão em lugar de Outro para esses entrevistados, são a essas figuras que eles endereçam uma demanda e fazem vínculo. Isso também se evidenciou nos exemplos relatados pelas assistentes sociais, onde elas pontuaram o retorno de pessoas que tomarão outros rumos, mas retornavam a associação para atualizá-las sobre suas vidas e escolhas; o caso em que uma das pessoas em situação de rua frequentadora do chá, trouxe a filha recém-nascida para elas conhecerem; ou ainda, quando outro frequentador da ação levou a tia para comprar no bazar da associação, com a "sua assistente social" sem permitir que ela comprasse com outra pessoa. As assistentes também relataram situações onde são presenteadas como forma de agradecimento, através de pacotinhos de bala, ou com produtos confeccionados por eles.

Entre os vários voluntários da associação, quem apareceu nos relatos desses sujeitos foi uma, a vó. Relação que ganha destaque pelo olhar que ela atribui aos entrevistados, a vó faz com que se sintam acolhidos e reconhecidos. Durante os dias em que ela participa do voluntariado se dirige até a fila em que as pessoas em situação de rua aguardam pelo chá para cumprimentar um a um. O diálogo, geralmente, se inicia dessa maneira: "Oi meus netos, vocês estão bem? Olha só você como está lindo hoje (...) Viu que nosso time ganhou ontem?”.

Nesse momento, surgem os sorrisos, as pessoas retribuem o cumprimento, abraçam e alguns pedem a benção à vó, que há vinte e três anos atua como voluntária junto à população em situação de rua e, há três nessa associação. Nos dias que ela não participa do voluntariado, sua falta é notada e sentida pelas pessoas em situação de rua. 


\section{CONSIDERAÇÕES FINAIS}

Entre as milhares de pessoas que vivem em situação de rua no Brasil, esta pesquisa limita-se a um público de dez pessoas, por esta razão representa de forma muito sútil esse universo. Foram diversas as motivações que levaram as pessoas entrevistadas a fazerem das ruas um espaço de moradia. Algumas das motivações foram marcadas por perdas, a exemplo de um dos entrevistados que, recém-chegado às ruas, encontra ali a possibilidade de não ser mais uma boca para o pai sustentar. Outras motivações foram marcadas por uma liberdade extrema, como no caso de uma das pessoas que ao romper com as exigências do mercado de trabalho, de custos em manter uma moradia, e de relações interpessoais, permite-se permanecer nas ruas por adorar a cidade.

Esses sujeitos encontraram, na rua, uma saída que no decorrer da vida não encontraram na relação com o Outro, constatação possível a partir da identificação dos laços estabelecidos dentro da associação e na rua. Notou-se ainda, o acolhimento das pessoas em situação de rua com o recém-chegado, através da indicação de locais onde conseguem comida e outros atendimentos e a alegria das pessoas ao reencontrá-los nesses locais. Também foi possível verificar a busca dos entrevistados por afeto, aprovação e encorajamento nos trabalhadores da associação, bem como, o afeto e o cuidado presente nos discursos dos entrevistados sobre eles.

Entre as histórias de vida ouvidas na pesquisa, encontraram-se sujeitos que na rua sustentaram o laço com o outro, como também aqueles que durante a estadia nas ruas se depararam com a rede de inserção desenvolvida pela assistência social e desejaram (re) estabelecer relações seja no mercado de trabalho ou na vida afetiva. Encontraram-se ainda, sujeitos que frente ao mesmo atendimento, ali permaneceram. Com isso, conclui-se que o único ponto em comum entre as pessoas entrevistadas é a rua, que enquanto um não lugar pode fazer parte da invenção dos sujeitos para o laço social.

\section{REFERÊNCIAS}

Brasil. Ministério do Desenvolvimento Social e Combate à Fome. (2009). Rua: aprendendo a contar. Pesquisa Nacional sobre a População em Situação de Rua. Brasília-DF: MDS; Secretaria de Avaliação e Gestão da Informação, Secretaria Nacional da Assistência Social, 2009. Recuperado de https://www.mds.gov.br/webarquivos/publicacao/ assistencia_social/Livros/Rua_aprendendo_a_contar.pdf

Brasil. Presidência da República. Casa Civil. (2019). Constituição da República Federativa do Brasil de 1988. Brasília-DF. Recuperado de http://www.planalto.gov.br/ccivil_03/ Constituicao/Constituicao.htm

Brasil. Secretaria de Direitos Humanos da Presidência da República. (2013). Diálogos sobre a população em situação de rua no Brasil e na Europa: experiências do Distrito Federal, Paris e Londres. Brasília: SDH. Recuperado de http://sectordialogues.org/sites/default/ files/acoes/documentos/publicacao_dialogos_sobre_a_populacao_em_situacao_de_rua_ no_brasil_e_na_europa.pdf 
Camargo, K. P., Berton, A. L. M., \& Gonçalves, S. C. (2015). Relatório final dos estágios curriculares: psicologia comunitária (Trabalho de conclusão de curso). Centro Universitário Franciscano do Paraná, Curitiba, PR, Brasil.

Conselho Regional de Psicologia do Paraná (CRP-PR). (2018, julho 17). Com aumento da violência contra população em situação de rua, CRP-PR e movimentos sociais cobram ações da prefeitura de Curitiba. Recuperado de http://crppr.org.br/com-aumento-daviolencia-contra-populacao-em-situacao-de-rua-crp-pr-e-movimentos-sociais-cobramacoes-da-prefeitura-de-curitiba

Crochík, J. L. (2006). Preconceito, indivíduo e cultura (3a ed.). São Paulo: Casa Psi Livraria.

Ferrari, I. Melancolia: de Freud a Lacan, a dor de existir. Latin-American Journal of Fundamental Psychopathology on-line, 1(1), 105-115. Recuperado de http://www. fundamentalpsychopathology.org.br/uploads/files/latin_american/v3_n1/melancolia_de_ freud_a_lacan.pdf

Freud, S. (2011). Psicologia das massas e análise do eu e outros textos 1920-1923. São Paulo: Companhia das Letras.

Instituto de Pesquisa Econômica Aplicada (IPEA). (2016). Estimativa da População em Situação de Rua no Brasil. Brasília; Rio de Janeiro: IPEA. Recuperado de http:// repositorio.ipea.gov.br/bitstream/11058/7289/1/td_2246.pdf

Lacan, J. (1998). Escritos. Rio de Janeiro: Jorge Zahar, 1998.

Lacan, J. (1964). O seminário, livro 11: os quatro conceitos fundamentais da psicanálise. Rio de Janeiro: Jorge Zahar.

Lacan, J. (1992). O seminário, livro 17: o avesso da psicanálise. Rio de Janeiro: Jorge Zahar. Lacan, J. (1975-1976). O seminário, livro 23: o sinthoma. Rio de Janeiro: Jorge Zahar.

Augé, M. (2012). Não lugares: introdução a uma antropologia da supermodernidade. Campinas: Papirus.

Movimento Nacional da População de Rua (MNPR) (2010). Conhecer para lutar. São Paulo: Instituto Polis. Recuperado de http://www.direito.mppr.mp.br/arquivos/File/MNPR_ Cartilha_Direitos_Conhecer_para_lutar.pdf

Nogueira Filho, D. (2001). Há diferença na clínica do toxicômano?. Acheronta: Revista de Psicanálise e Cultura, 13(1). Recuperado de https://www.acheronta.org/acheronta13/ toxicomano.htm

Ortega y Gasset, J. (2001). A rebelião das massas. E-book. Recuperado de http://www. ebooksbrasil.org/eLibris/ortega.html

Sasse, C., \& Oliveira, N. (2019). Invisível nas estatísticas, população de rua demanda políticas públicas integradas. Brasília-DF: Senado Federal. Recuperado de https://www12.senado. leg.br/noticias/infomaterias/2019/03/especial-cidadania-populacao-em-situacao-de-rua

Soler, C. A hipótese lacaniana. Percurso, 29(2), 5-13. Recuperado em http://revistapercurso. uol.com.br/index.php?apg=artigo_view\&ida=788\&ori=autor\&letra $=S$ 
Veras, M. (2009). A loucura entre nós: a teoria lacaniana das psicoses e a saúde mental (Tese de Doutorado). Programa de Pós-graduação em Psicologia, Universidade Federal do Rio de Janeiro, RJ, Brasil. Recuperado em dia, mês, ano, de www.dominiopublico.gov.br/ pesquisa/DetalheObraForm.do?select_action=\&co_obra=150298

Wollmann, A. (2018). A rua como território do cuidado: uma experiência sobre a produção de saúde da população inviabilizada (Dissertação de Mestrado). Setor de Ciências Sociais Aplicadas, Universidade Federal do Paraná, Curitiba-PR, Brasil. Recuperado de https:// acervodigital.ufpr.br/bitstream/handle/1884/58491/R\%20-\%20D\%20-\%20ADRIANE\%20 WOLLMANN.pdf?sequence $=1$ \&isAllowed $=y$

Recebido em: 20-02-2020

Primeira decisão editorial: 08-04-2020

Aceito em: 30-04-2020 